\title{
Komentarze
}

\section{Przed tajemnicą}

Andrzej Franaszek

TEKSTY DRUGIE 2019, NR 1, S. 240-256

DOI: 10.18318/td.2019.1.16 | ORCID: 0000-0002-8573-0154

Biograf musi iść przed nami, jak kanarek w kopalni, sprawdzać atmosferę, wykrywać fałsz, nierzeczywistość i obecność przebrzmiałych konwencji. Musi uruchomić i uwrażliwić całe swoje wyczucie prawdy. Do tego, ponieważ żyjemy w czasach, kiedy gazety, listy i dzienniki ze wszystkich stron kierują tysiące kamer na każdą postać, biograf musi być przygotowany na to, by godzić sprzeczne wersje tej samej twarzy.

Virginia Woolf

- Powiedział pan przed chwila, iż mnie pojmuje - odezwał się,jakbyśmy nie przestali rozmawiać. - Nie sądzę, żeby pan mnie rozumiał. Jakże mógłby mnie pan pojąć, skoro ja sam siebie nie pojmuję.

- Biograf...

- Och, biografowie. Biografowie to po prostu powieściopisarze bez wyobraźni!

Peter Ackroyd ${ }^{2}$
Andrzej Franaszek

(ur. 1971) - krytyk literacki, wykładowca Uniwersytetu Pedagogicznego w Krakowie, sekretarz Międzynarodowej Nagrody Literackiej im. Zbigniewa Herberta. Autor książek Miłosz. Biografia (2011) i Herbert. Biografia (2018), a także publikacji Ciemne źródło. Esej o cierpieniu w twórczości Zbigniewa Herberta (1998 i 2008) oraz Przepustka z piekła. 44 szkice o literaturze i przygodach duszy (2011).Kontakt: franaszek@pro. onet.pl

1 V. Woolf Sztuka biografii, w: tejże Eseje wybrane, przeł. M. Heydel, Karakter, Kraków 2015, s. 321.

2 P. Ackroyd Dickens, przeł. D. Filipczak, „Literatura na Świecie” 1999 nr 7/8. 
"Co nie jest biografią - nie jest w ogóle"3 - notował we Florencji pod koniec o wiele zbyt krótkiego życia Stanisław Brzozowski, i choć to często przywoływane zdanie wieńczy znacznie bardziej złożony wywód, tu wystarczy przypomnieć jedynie finałową formułę, mającą tonację niepodważalnej sentencji. I dodać do niej choćby to - sformułowane podczas rozmyślań o poezji Julii Hartwig - zdanie Czesława Miłosza: „każdy wiersz liryczny jest cząstką autobiografii, nawet jeżeli nic w nim nie ma z wyznań"4

Głęboko wierzę w sens takiego właśnie myślenia o literaturze czy raczej - o siatce kultury, tworzonej przez człowieka, siatce oddzielającej nas od nie-ludzkiego, obojętnego świata, ostatecznie zaś - od śmierci. Oczywiście nie mam na myśli jakiejś naiwnej, zaprzeszłej i w gruncie rzeczy czysto hipotetycznej „biograficzności”, mającej objaśnić każde dzieło wydarzeniami z życia jego twórcy. Jestem natomiast przekonany, że równie zubożające dla krytyka czy historyka literatury jest pominięcie biograficznego wymiaru, całkowita (i prowadząca nieraz na manowce) swoboda interpretacyjna, rezygnacja z prób odczytania prawdziwej intencji autora, rezygnacja z powiązania, w jakkolwiek skomplikowany sposób musi się to odbywać, owego „dzieła” i „życia”. By krytykować jedynie samego siebie: przed dekadami, pisząc o tym, jak poezja Zbigniewa Herberta mierzy się z tematem cierpienia, analizowałem m.in. wiersz Pan Cogito - zapiskiz martwego domu. Pamiętałem o Dostojewskim, szukałem inspiracji filozoficznych czy religijnych, odnajdując w tym utworze zapis mrocznej epifanii. Dziś wiem również, że jest to utwór, w którym poeta odwołał się do doświadczenia zniewolenia, jakiego sam doznał podczas pobytów w szpitalach psychiatrycznych, i sądzę, że dopiero połączenie tych perspektyw pozwala ów wiersz w pełni zrozumieć.

Jest w tym zresztą, być może nabywana dopiero z wiekiem, trudno zaś dostępna młodemu ambitnemu akademikowi, ciekawość innego człowieka, jego duszy odciskającej się w twórczości, ale też zwykłych życiowych kolein, tego, jak radził on sobie ze swoim życiem, jak duchowo dojrzewał, jakie odnosił zwycięstwa i jakie ponosił klęski. Potrzeba zadania choćby najprostszych pytań: ile miał lat, co zdążył zrozumieć ze świata, gdy formułował w swym utworze taki lub inny sąd. Dopowiedzmy szczerze: gdzieś w tej ciekawości kryje się także chęć znalezienia jeśli nie odpowiedzi, to przynajmniej podpowiedzi na najbardziej podstawowe i brzmiące przy tym najbardziej naiwnie pytania o sens własnego życia. Wydawać by się zatem mogło, że jesteśmy tu daleko

3 St. Brzozowski Pamiętnik, Czytelnik, Warszawa 2000, s. 126.

4 Cz. Miłosz *** [Opinia o tomie Julii Hartwig pt. "Zobaczone"], "Zeszyty Literackie" 2000 nr 69. 
od obiektywnej perspektywy badacza, myślę przecież, iż w rzeczywistości prawie każda polonistyczna działalność wiąże się z osobistym, choć nieraz skrywanym, zaangażowaniem. A już z pewnością tak być musi w przypadku konfrontowania się z czyimś życiorysem. Gigant brytyjskiej biografistyki Peter Ackroyd zwierzał się niegdyś: „moje zainteresowanie przeszłością [... ] polega [...] na umiejętności empatii. [...] Próbuję zrozumieć charakter postaci żyjących w przeszłości, a one promieniują na moją pracę, na moje myślenie. Kiedy idę ulicami Londynu, czuję żywą obecność przeszłości tak samo mocno, jak czuję chwilę obecną"5. Ja zaś, w porównaniu z Ackroydem początkujący autor dwóch książek, skoro nie jest mi dana aż taka intensywność doznań, powtarzam przynajmniej prośbę „żebym rozumiał innych ludzi inne języki inne cierpienia", wspaniałe słowa, które Herbert zawarł w Modlitwie Pana Cogito - podróżnika. Tak właśnie: innych ludzi, inne języki, a zwłaszcza inne, tak nieraz skomplikowane i trudne do pojęcia, cierpienia.

Przyznam jeszcze, że łatwiej jest mi pisać biografię, niż dywagować o procesie jej powstawania, dobrze czuję się w kontakcie z konkretem czy to cudzego życia, czy to cudzej twórczości, podczas zbierania, analizowania, układania, a wreszcie: prób rozumienia; nie zaś wtedy, gdy z tych aktywności trzeba wysnuć prawidła lub teorię. Właściwie nie potrafię wyobrazić sobie samego siebie, jak prowadzę warsztaty pisania biografii, pocieszając się tutaj wspomnieniem Krzysztofa Mętraka o twórcy Pociagu i Austerii Jerzym Kawalerowiczu, który „wyszedł z wykładu w szkole filmowej po 30 minutach. Nie dotrwał do 45. Powiedział wszystko o tym, jak się robi filmy"6. Tak więc spiszę jedynie parę uwag praktyka. Chaotyczną pogadankę na może nieco więcej niż pół godziny.

\section{*⿻一从火}

„Z radością opowiem Panu mnóstwo rzeczy o Zbyszku, on był naprawdę fenomenalny" - słyszałem nieraz w słuchawce telefonu, rezerwowałem zatem całe popołudnie na spotkanie, by następnie przekonać się, że po jednym, dwóch, najdalej trzech kwadransach rozmówca zaczyna się powtarzać, a tak naprawdę z całego wywiadu zostanie pojedyncza, nie zawsze dobra, anegdota. Nie wymądrzam się tutaj, sam bowiem parę lat temu byłem indagowany przez

5 Samo pisanie. Z Peterem Ackroydem rozmawia Jerzy Jarniewicz, "Literatura na Świecie” 1999 $\mathrm{nr} 7 / 8$.

6 K. Mętrak Dziennik 1969-1979, oprac. W. Holewiński, Iskry, Warszawa 1997, s. 119. 
Katarzynę Kubisiowską, autorkę biografii Jerzego Pilcha, i z niedowierzaniem musiałem sobie uzmysłowić, jak mało potrafię przywołać z tych tysięcy chwil, które razem z Jurkiem spędziłem w redakcji „Tygodnika Powszechnego”, jak wiele zapomniałem nie tylko konkretnych faktów, ale nawet własnych emocji. Tak więc z żyjącymi świadkami biograf ma nieraz kłopot, a przecież prawdziwe trudności zaczynają się wtedy, gdy musimy zdecydować, czy wierzyć w to, co słyszymy: może wszak naszego rozmówcę zawodzi pamięć, a może rekonstruuje on wydarzenia z przeszłości, rzutując na nie sprawy późniejsze, choćby przykre zakończenie przyjaźni z bohaterem naszej książki. Teoretycznie powinniśmy założyć, że potrzebne są zawsze przynajmniej dwa źródła, dwa zgadzające się z sobą świadectwa, w rzeczywistości jednak zwykle tak nie będzie, musimy polegać na intuicji, na własnym osądzie, odczuciu prawdopodobieństwa.

Oczywiście bywa tak, że rozmowa przynosi bardzo wiele $\mathrm{i}$ to nie tylko w warstwie faktograficznej, ale rozjaśniając zasadnicze kwestie, podczas pracy nad biografią autora Struny światła ważnymi rozmówcami byli dla mnie choćby Barbara Toruńczyk, Zdzisław Najder czy Adam Zagajewski, a zwłaszcza Katarzyna Herbert - zaprzeczenie wszystkich negatywnych stereotypów związanych z rolą „wdowy po artyście”. Jednakże, generalnie rzecz biorąc, bardziej niż w ludzką pamięć wierzę w dokumenty, zachowane ślady, zapisane strony, których szczęśliwie nie skąpią publikacje i archiwa moich bohaterów. Przy czym, jeśli korzystanie z artykułów lub listów Czesława Miłosza przypomina ewangeliczną opowieść o łowieniu ryb, gdy sieć biografa zda się nieledwie pękać od zdarzeń, sądów, informacji, to podobny proces w przypadku Zbigniewa Herberta budzi skojarzenie z mozolnym poszukiwaniem złota, przesiewaniem przez sito ton materiału, by od czasu do czasu, pośród błahych lub ogólnikowych treści wybłysnął biograficzny kruszec. Oczywiście w tym drugim porównaniu jest przesada, autor Raportu z oblężonego Miasta także pisywał szczere, obszerne listy, czynił to jednak bez porównania rzadziej od autora Ocalenia, o wiele częściej ukrywał się za dowcipnymi pozdrowieniami na pocztówkach, nie udzielał wywiadów rzek, nie spisywał wspomnień. Nieraz napomykał, że chciałby - niczym tak przez niego ceniony Piero della Francesca - zupełnie zniknąć w swoim dziele, jeśli zatem jako biograf właściwie sprzeniewierzam się temu zamysłowi pisarza, mogę jako argument na swoją obronę przywołać jedynie fakt, że i Herbert - tak samo jak Miłosz - pozostawił po sobie olbrzymie, pełne prywatnych treści archiwum. Wydaje się bowiem, że obaj - co jest naprawdę frapujące - niczego nie wyrzucali, przeciwnie - zachowywali, a często z mozołem przewozili z kontynentu 
na kontynent każdy zapisany skrawek, niezależnie od tego, czy dotyczył on spraw fundamentalnych i boleśnie intymnych, jak te listy, w których Miłosz opowiadał o chorobie psychicznej swego syna, czy zupełnie błahych, jak paruzdaniowe wiadomości od amerykańskich studentów, notki zostawione może na biurku goszczącego w Kalifornii profesora, które dziś znajdziemy pośród dokumentów Herberta.

W przypadku pisania biografii nie istnieje nic takiego jak „embarras de richesses", ważna jest natomiast cierpliwość, mozolna praca, zwłaszcza że przypadku takich postaci jak obaj przywoływani poeci istnieje także olbrzymia „literatura przedmiotu”, obejmująca i studia krytycznoliterackie, i prace związane z rozmaitymi kontekstami, choćby kulturalną złożonością i konfliktami międzywojennego Wilna czy Lwowa. James L. Clifford, badacz XVIII-wiecznej kultury angielskiej, w książeczce o znamiennym tytule Odkamyków do mozaiki zauważa skromnie: „biograf musi zacząć od przyswojenia sobie wszystkiego, co napisano dotychczas o jego bohaterze"7 , by po chwili z nieco przerażającą sumiennością uszczegółowić swą radę: „komu przyszłoby na myśl, że można znaleźć coś ciekawego w archiwach kanałów ściekowych? A jednak księgi opłat ściekowych [...] zawierają bardzo pożyteczne wiadomości. Poborcy chodzili wzdłuż ulicy od domu do domu, inkasując pieniądze raczej od lokatorów niż od właścicieli i często wpisana uwaga, taka jak «wyprowadził się w zeszłym miesiącu», bywa dokładniejszą informacją od zapisów w księgach najmu. [...] Badacz nigdy nie może mieć pewności, gdzie

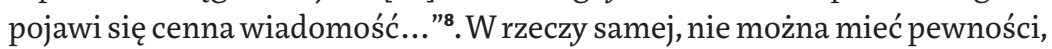
choć świadomość tego sprawia, że otwiera się pod stopami otchłań nigdy nie zakończonych poszukiwań.

Otchłań, a zarazem i pokusa, bo wszak te poszukiwania są bodaj najbardziej ekscytującą częścią naszej pracy, zaś Zbigniew Herbert, który sam długimi latami zbierał materiały do esejów, stwierdzał z autoironią, że dopiero potem zaczyna się prawdziwa „męka: młócka, mielenie, wypiekanie bułeczek” Nie ma zatem powodu, by narzekać na nadmiar lektur czy wędrówek, ja zaś, choć oczywiście nie mam tak spektakularnych doświadczeń jak Clifford, który miesiącami próbował odkupić od podejrzliwego szkockiego farmera unikalne dokumenty (zachowane, a jakże, w szufladzie zapomnianego na

7 J.L. Clifford Od kamyków do mozaiki. Zagadnienia biografii literackiej, przeł. A. Mysłowska, Czytelnik, Warszawa 1978, s. 11.

8 Tamże, s. 88.

9 Cyt. za: A. Franaszek Herbert. Biografia, Znak, Kraków 2018, t. 1, s. 738. 
strychu biurka), wędrowałem jedynie do kolejnych bibliotek i prywatnych mieszkań, starałem się przynajmniej zrobić to jak najrzetelniej. Niczego nie zlekceważyć, wykonać jeszcze jeden telefon, napisać jeszcze jeden mail, kupić kolejny bilet, dotrzeć do jeszcze jednej biblioteki...

Każda zaś biblioteka, każdy tzw. zasób archiwalny to dla biografa nowa nadzieja, przynoszące wiele emocji spotkanie, u którego początku wertujemy katalog, wypełniamy komputerowe lub nadal jeszcze papierowe zamówienia, niecierpliwie czekamy, aż kustosz złoży na stole pierwszą teczkę, zaopatrzywszy nas wcześniej w filcowe podkładki, wypełnione ołowiem sznureczki do przyciskania stron, czasem też - lupę. Nigdy nie wiemy, co naprawdę przyniesie kolejny dzień pracy, czy z setek przejrzanych stron wypiszemy długie akapity, czy jedynie dwa zdania, albo czy nie okaże się, że zbiory nie są aż tak dobrze uporządkowane, że w zamówionej pod wpływem impulsu teczce odkryjemy zawieruszony tu list, z radością rozpoznając znany nam już charakter pisma. Jeśli coś jest pewne, to fakt, że będziemy mogli pracować z tekstem najbardziej oryginalnym, najbliższym wręcz ciała twórcy, z rękopisami lub opatrzonymi poprawkami maszynopisami utworów nieraz zapierających nam dech w piersiach. Istnieją oczywiście pisarze nie znaczący okolic biurka pokreślonymi brulionami, jak Zygmunt Haupt, który - przynajmniej we wspomnieniach syna - „zwykł zamykać się w pracowni i długimi godzinami siedział tam «bezczynnie» nad maszyną do pisania, bez postawienia jakiegokolwiek znaku na czystej karcie [...]. W pewnym momencie zaczynał jednak wystukiwać zaplanowany tekst, robił to praktycznie bez żadnych przerw, zazwyczaj podczas jednego posiedzenia, nie pozostawiając jakichkolwiek widocznych odrzutów"10. Herbert postępował wszakże zupełnie inaczej, w jego notatnikach widzimy dosłownie rodzenie się tekstu, myśl, która odkrywa swój ostateczny kształt, nieraz długo i żmudnie" ${ }^{11}$ Także u Miłosza znajdziemy liczne warianty czy skreślenia, a także słynne już małe rysuneczki - przede wszystkim kwiatów, wykwitających między liniami wierszy - ślad twórczej drogi. I jak wiele potrafi powiedzieć choćby lista fraz mogących być tytułem poetyckiego zbioru, nad którymi zastanawiał się pisarz, by ostatecznie wybrać połączenie słów Światło dzienne.

P. Panas „Balon"Zygmunta Haupta.Zarchiwum pisarza, w: Archiwa i bruliony pisarzy. Odkrywanie, red. P. Bem, M. Prussak, Ł. Cybulski, Wydawnictwo IBL PAN, Warszawa 2017, s. 207. Herberta. Studia nad procesem tekstotwórczym, red. M. Antoniuk, Wydawnictwo UJ, Kraków 2017. 
Ale praca w archiwum ma w sobie coś bardziej zmysłowego i pierwotnego niż tekstologiczne śledztwa. W komentarzu tłumacza do klasycznej rozprawy Jacques'a Derridy Gorączka archiwum znajdziemy wskazówkę, że francuski myśliciel w swych rozważaniach „wykorzystuje grę słów, której nie sposób oddać w polszczyźnie. «Cœur» oznacza, rzecz jasna, serce, również w wykorzystywanym przez filozofa znaczeniu środka, centrum, zasady, istoty rzeczy. Zaś idiom «par cœur» oznacza «na pamięć». Tak więc w wykładni Derridy pamięć łączy się zarówno z aktem upamiętnienia, jak i z ciałem"12. My zaś poprzez zmaterializowaną pamięć archiwum wędrujemy cieleśnie, gdyż czytając notatniki, listy, pocztówki, jednocześnie - tylko z pozoru to banalna konstatacja - dotykamy ich. Dlatego właśnie badacz i edytor, Adam Dziadek, który wiele dni spędził w archiwum Aleksandra Wata, przyznaje, iż w trakcie takich spotkań „trudno opanować emocje. [...] Idzie głównie o sprawę dotyku, dotykania tych samych stronic, zapisanych ręką twórcy. Nie ma w tym naiwności ani emfazy"13.

Moim zdaniem rzeczywiście nie ma. Przy czym bodaj każde archiwum, a już z pewnością archiwum Zbigniewa Herberta, autora utworu o tytule Piosenka o rzeczach zbędnych, przechowuje także przedmioty inne niż najbardziej oczywiste ślady tzw. procesu twórczego. Kiedyś już o tym pisałem, pozwolę sobie zatem w najbliższych liniach zacytować samego siebie. Powtórzyć, że jeśli w swych wierszach Herbert właściwie wymazywał obecność autora, a przynajmniej ją zasłaniał, to $\mathrm{w}$ obrębie egzystencjalnej praxis gromadził wszystko to, co dokumentowało i jakby utrwalało jego istnienie. W jego archiwum trwają zatem nie tylko rękopisy i maszynopisy, książki i kserokopie, listy i dyplomy, ale także nie polizane jeszcze znaczki i już przedziurawione bilety tramwajowe, banknoty i monety, kurpiowskie wycinanki i zasuszone kwiaty. Kalendarzyk ze schowaną tu żyletką i pastylka na dobry sen, która miast trafić do ust, tkwi przyklejona do pewnego listu. Włoska ulotka ze słowami „No! No!! No!!!", dopisanymi nad nazwą leku mającego bronić przed depresją. Podkładka do piwa, na której poeta naszkicował siebie oraz swą kochankę; pobrzmiewający znajomo w uszach czytelnika Barbarzyńcy w ogrodzie granatowy kartonik „Albergo Fiore - Napoli”; wąski pasek wizytówki, z którego bije w oczy słowo „Vivien”, imię prostytutki z Pireusu, obok zaś bilet wizytowy „Joseph Czapski”, na którym malarz dopisał numer telefonu.

12 J. Momro, przypis w: J. Derrida Gorq̨czka archiwum. Impresja freudowska, przeł. J. Momro, Wydawnictwo IBL PAN, Warszawa 2016, s. 24 
Jaskrawo czerwona ulotka paryskiej knajpki „China Belleville”, karty menu, wyniesione $\mathrm{z}$ niemieckich restauracji, adres trattorii z dopisaną adnotacją „Mama ze Spoleto". Legitymacja członka Komitetu Obchodów 25. rocznicy Poznańskiego Czerwca 1956, a obok wymięta i poplamiona zielonym tuszem tekturka z myślą Faulknera o tym, że pisarz nie ma prawa się bać. Maleńka niczym pół pudełka zapałek reprodukcja obrazu „Jezu ufam Tobie”, z napisem na odwrocie „Najdroższej Córuchnie - Mamusia, 1 sierpnia 1959”. Opłatek, wysłany poecie z ponurego Krakowa lat stalinowskich. Wreszcie wycięte z gazety zdjęcie Paula Celana ${ }^{14}$.

Myślę, że takie wyliczenie - bardzo dalekie od kompletności - odsłania jedno z pasm duszy człowieka, którego chcemy zrozumieć. I jestem też pewien, że biograf wszystkich tych rzeczy powinien dotknąć, nie zaś jedynie zobaczyć - w postaci zdjęcia czy skanu. Zapewne nie doprowadzi go ów dotyk do mistycznej partycypacji w ich istnieniu, ale przynajmniej będzie z nimi obcował dłużej i spokojniej. Podczas pracy nie powinien się bowiem śpieszyć, przeciwnie - warto, choć wiąże się to raz jeszcze z niebezpieczeństwem nieukończenia, by cokolwiek ją przedłużał. Sam wszak w tym czasie duchowo dorasta (niektórych spraw nie mógłby zaś pojąć, gdyby nie zgromadził puli doświadczeń we własnym życiu), a jednocześnie coraz głębiej wchodzi w świat bohatera, gęstnieje w nim tkanina cudzej egzystencji. W tym procesie pomagają podróże, zobaczone na własne oczy miasta czy domy, na poły machinalnie przemyślane zagony czasu, no i naturalnie spotykani ludzie, podpowiadający, gdzie jeszcze powinniśmy zajrzeć, co przeczytać. Sądzę, że jeśli zdarzają się tu tzw. szczęśliwe przypadki, choćby „odnalezione cudem” materiały, to jedynie wtedy, gdy na ów cud solidnie zapracowaliśmy.

\section{*⿻*从一}

Łatwo zatem zrozumieć, że dobra biografia powstaje przez wiele lat, czasem zresztą takie doświadczenie organizuje nam nieledwie resztę życia, gdy wśród innych badaczy, komentatorów stajemy się jakby cząstką warkocza komety, której jądro nosi nazwę „Miłosz”, „Herbert”,,Iwaszkiewicz"lub „Gombrowicz”. Jeździmy na konferencje, zaprzyjaźniamy się z tymi, którym "nasz bohater” jest równie bliski, zażarcie dyskutujemy, o czym właściwie myślał on pewnego poranka przed 75 laty. Co ważniejsze, często we własnych sprawach myślimy poprzez niego, nawet jeśli oznacza to: jemu na przekór.

14 Por. A. Franaszek Herbert: Cały ten kram życia, „Pismo. Magazyn opinii” 2018 nr 3. 
Z innej strony patrząc: nieśpieszny proces powstawania takiej książki kłóci się z rytmem współczesnego życia literackiego, a już zwłaszcza rynkowego, które domaga się efektów możliwie natychmiastowych. W polskich warunkach nie możemy liczyć na naprawdę hojne wieloletnie stypendia, właściwie powinniśmy być doskonale uposażonym, XIX-wiecznym dżentelmenem, który z własnych zasobów finansuje swe badania. Środki państwowe są ograniczone, w ostatnim zaś czasie - boleśnie upolitycznione, prywatnych mecenasów o wiele mniej niż chętnych do korzystania z ich pomocy. W takiej kolejce będzie zresztą biograf usytuowany gdzieś daleko za filmowcem, plastykiem czy nawet powieściopisarzem; książek biograficznych Polacy czytają co prawda coraz więcej, niewątpliwie jednak daleko nam jeszcze do świata anglosaskiego, gdzie w księgarniach możemy wybierać między paroma obszernymi tomami, opisującymi życie Prousta, Larkina czy Sylvii Plath. Ale też sama warstwa kultury jest u nas cieńsza, bardziej powierzchowna, mniej zakorzeniona w społeczeństwie. O wiele słabsze zdaje się również poczucie ciągłości, inaczej niż w Wielkiej Brytanii, w Polsce postaci z XVII, XVIII, ba, nawet XIX stulecia zdają się interesować tylko wąskie grono fachowców. Winna zapewne chaotyczna historia, także ta najnowsza, powojenne społeczne przewroty, ale może również - na głębszym poziomie - to, że brakuje nam owej empatii, o której mówi cytowany już Ackroyd, przekonując, że co prawda, w przeciwieństwie do Francuzów „Anglicy nie potrafią przeprowadzać subtelnych analiz” - za to jednak posiadają „zdolność głębokiego, emocjonalnego rozumienia własnego i cudzego życia"15. A my, Polacy? Dość rzadko chyba się cechą tą wykazujemy, przynajmniej jeśli mogę sądzić na podstawie nie tylko dziennikarskich notek, ale też niestety niejednej recenzji z biografii Zbigniewa Herberta, których autorzy - wbrew wszelkim wysiłkom piszącego te słowa - potrafili w życiu poety dostrzec jedynie alkohol, chorobę psychiczną, niewierności.

*⿻*

Biograf nie jest oczywiście artystą w tym sensie, w jakim jest nim poeta, o wiele bliżej mu do (mniej lub bardziej wytrawnego) rzemieślnika. Sam zresztą nie przepadam za tymi próbami biograficznymi, których autorzy prezentują zbeletryzowaną opowieść, a czasem wręcz wymyślają sceny lub dialogi. I choć między wywiadem z Denisem Diderotem, który z pomocą 
kasetowego magnetofonu zarejestrował Hans Magnus Enzensberger ${ }^{16}$, albo też rozmowami, jakie Ackroyd kazał odbyć duchowi Dickensa z postaciami z jego powieści ${ }^{17}$, a niektórymi próbami naszych rodzimych autorów widać dojmującą różnicę, to zasada wydaje mi się ta sama. Tworząc biografię, powinniśmy starać się o możliwą przeźroczystość, nie epatować swoją osobą, odłożyć na półkę przesadne literackie ambicje, pisać oczywiście jak najlepiej, ale bez zamysłu rywalizowania z twórcami porywających nas fikcji.

A jednak praca biografa - jak ujmowała to Virginia Woolf i co możemy jako pocieszające motto zawiesić nad biurkiem - „jest bezcenna; nigdy nie wyrazimy mu pełnej wdzięczności za to, co dla nas robi. [...] Wyobraźnia to zdolność, która szyblko się męczy, potrzebuje odpoczynku i odświeżenia. Dla zmęczonej wyobraźni odpowiednią dietę zapewni nie podrzędna poezja czy drugorzędna proza - one w istocie ją tępią i zanieczyszczają - ale trzeźwe fakty [...]. Gdzie i kiedy żył ów prawdziwy człowiek, jak wyglądał, czy nosił sznurowane trzewiki, czy sztyblety, kim były jego ciotki i jego przyjaciele; jak wydmuchiwał nos; kogo kochał i jak". Tak zatem - przekonuje autorka Pani Dalloway - biograf nie tylko gromadzi informacje, ale „może dać nam fakt twórczy, fakt żyzny, fakt, który sugeruje i zapładnia"18. Dodajmy, że jeśli nawet nie zapładnia do twórczości, to przynajmniej do rozwijania empatii, która przyda nam się w najbardziej codziennym życiu, podczas wyborów zarówno prywatnych, jak i politycznych.

Sądzę przy tym, że biograf nie powinien do pracy przystępować z w pełni gotowym zamysłem, poczuciem sprawowania całkowitej władzy nad przyszłą opowieścią, raczej podążać za chwilowymi nawet intuicjami, za tym, co podpowiadają pojawiające się stopniowo materiały. Dobrze się stanie, jeśli na pewien sposób nasza książka będzie mądrzejsza od nas, jeśli w trakcie jej pisania ujawnią się takie aspekty życiorysu, takie korespondencje między wydarzeniami czy utworami, z których jeszcze przed chwilą - nawet układając drobiazgowy plan - nie zdawaliśmy sobie sprawy. Gdy zresztą prześledzimy wywiady z brytyjskimi biografami, jakie pod koniec lat 50. ubiegłego stulecia przeprowadził przywoływany już James L. Clifford, to nawet jeśli ich nazwiska niewiele nam dziś mówią, pozostanie dla nas ciekawa niechęć tych nieżyjących już autorów do z góry założonego schematu, przesadnego zdefiniowania.

16 Por. H.M. Enzensberger Diderot i ciemne jajo (rozmowa z gościem), przeł. A. Kopacki, „Literatura na Świecie" $1999 \mathrm{nr} 7 / 8$.

Por. P. Ackroyd Dickens... 
Dłuższą opowieść Clifford konkluduje: „wnioskiem, jaki wyciągnąłem z tej serii rozmów było to, że najlepsi biografowie uważają się za twórców. Nie uznają żadnych ogólnych zasad i lekceważą teorie krytyczne"19; zaś któryś z jego rozmówców „nigdy nie stawiał sobie pytania, dlaczego wybiera tę informację, zamiast tamtej. Uważał, że był to przeważnie wybór intuicyjny. [...] uważał się za pisarza"20.

Mniejsza o słowa „pisarz”,, ,artysta” - ważniejsze wydaje mi się owo zaakceptowanie intuicji, bo jest w tym geście także pokora wobec skłębionej materii cudzego życia. Jak staramy się nie epatować własnym „ja” w przestrzeni stylistyki, tak też nie możemy poddać opowieści o naszym bohaterze żadnej tezie, a zwłaszcza dążyć do zaspokojenia potrzeb tych licznych czytelników, którzy oczekują od nas „pozytywnego” lub „negatywnego” obrazu. Musimy umknąć uproszczeniom, choć zwykle o wiele wygodniej podzielić świat na pola czarne i białe, niż mozolnie śledzić odcienie szarości. Moglibyśmy nawet przyjąć, że jeśli - osobliwie w dzisiejszych czasach, zachęcających do myślowego prostactwa - autor biografii jest atakowany zarówno przez prawicę, jak i lewicę, zarówno z pozycji, powiedzmy, feministycznych, jak i konserwatywno-katolickich, świadczy to o nim dobrze, umknął bowiem zaszeregowaniu, nie dał się zaciągnąć pod żadne sztandary. A życiorysy przynajmniej tych dwóch pisarzy, których poznałem naprawdę dobrze, zupełnie nie nadają się do stworzenia z nich w stu procentach jednoznacznej opowieści, wyłamują się z czarno-białych podziałów, zarówno moralnych, jak i politycznych.„Był człowiekiem bardzo skomplikowanym, nieraz pełnym sprzeczności" - odpowiadam, jakże błyskotliwie, na równie błyskotliwe pytanie „jakim człowiekiem był Zbigniew Herbert?", chętnie zadawane na spotkaniach autorskich. Myślę, że akceptacja takiej złożoności to test na dojrzałość, o którą nieraz jest nam trudno. Może zwłaszcza nam, Polakom, przywiązanym do jednoznacznych podziałów i ocen.Z tej perspektywy patrząc, biograf sytuowałby się na myślowym biegunie dokładnie przeciwnym temu, jaki zazwyczaj okupuje polityk.

\section{*⿻一从火}

Oczywiście krążymy tu wokół słowa „obiektywizm”, wartości, której nigdy nie osiągniemy w pełni, nie jesteśmy wszak Bogiem, do której jednak musimy dążyć. Bardzo łatwo jest ją zaprzepaścić, biograf ma rozliczne możliwości

19 J.L. Clifford Od kamyków do mozaiki..., s. 136.

20 Tamże, s. 140. 
manipulacji, jeśli chce skrzywdzić swego bohatera, nieraz wystarczy, by choćby urwał jakiś cytat o parę słów przedwcześnie; jeśli chce jego wizerunek poprawić - może z kolei o różnych wypowiedziach zapomnieć. Obiektywizm jest zresztą tym trudniejszy do osiągnięcia, im więcej emocji wiąże nas z człowiekiem, o którym piszemy, a pisanie biografii osoby, wobec której nie czujemy pasji - nie ma, jak sądzę, najmniejszego sensu. Musimy odczuwać jakieś, choćby ułomne, porozumienie, odnajdywać pokrewieństwo, co oczywiście nie oznacza, że - jak to lubią sobie czasem wyobrażać czytelnicy - biograf utożsamia się ze swoim bohaterem. O ile nie dotyka go szaleństwo, to z pewnością się nie utożsamia, nie może jednak być mu obcy, a kwestia intensywności tych związków jest tyleż bardzo złożona, co nader indywidualna.

$\mathrm{Z}$ mojego punktu widzenia zasadnicza różnica wiąże się przy tym $\mathrm{z}$ faktem osobistego poznania człowieka, o którym piszę. Pamiętam wiele spotkań z Czesławem Miłoszem, odłożyła się we mnie ich aura, czy może raczej różne aury, od chwil przerażeń, że mam rozmawiać właśnie z Nim, z Poetą pisanym i myślanym wielką literą, aż do pasm czułości, do zapamiętanego uśmiechu, koloru oczu, sposobu uściśnięcia dłoni. Nie umiem tego nazwać inaczej niż kształtem miłości, co nie znaczy, że jest to uczucie oślepiające, każące mi „wybielać" bohatera, na siłę usprawiedliwiać lub tuszować jego poczynania. Ze Zbigniewem Herbertem wymieniłem jedynie parę listów, najważniejszym z nich był ten, dzięki któremu w „Tygodniku Powszechnym” ukazał się szkic poety poświęcony Jerzemu Turowiczowi - doskonale oddający znaczenie zarówno osobowości, jak i moralnej busoli naszego Szefa. Poezja autora Pana Cogito była dla mnie ważna "od zawsze”, czyli od chwili, gdy miałem może 15 lat i zacząłem ją poznawać, z początku - bądźmy szczerzy - w szkolnym podręczniku. Nieco dojrzawszy, pisałem o niej pracę magisterską, w obrębie promieniowania tych wierszy pozostawałem przez dziesięciolecia. Nigdy przecież nie mogłem doznać tego rodzaju bliskości, jaka została mi ofiarowana przez Miłosza, nie zawarłem z Herbertem podobnego paktu zaufania. Raz jeszcze powtórzę: paktu, który nie prowadzi do „biograficznej ślepoty”, ale z pewnością wpływa na rozumienie, oceny, temperaturę emocji.

Nie prowadzi do ślepoty także dlatego, że pisząc biografię, prędzej czy później musimy, jeśli nie aż „zdradzić” bohatera, to mu się sprzeniewierzyć, stopniowo bowiem bliższa nam się staje przez nas samych odkrywana prawda (lub mówiąc ostrożniej: nasza wersja prawdy) niż ta opowieść, którą sam ów bohater chciałby o sobie przekazać. Przywiązujemy się do własnej, coraz bardziej dogłębnej, wiedzy, chcemy ją przekazać, trudno jest zrezygnować z odnalezionych, nawet najbardziej kontrowersyjnych, informacji, nie „pochwalić 
się" nimi przed czytelnikiem. Zwłaszcza że żyjemy w epoce ekscytującej się odsłanianiem tego, co najbardziej intymne. Wędrujemy tu po wąskiej granicy między prawdziwością portretu, a żerowaniem na prywatności, musząc zastanawiać się choćby, czy wzmianka o kolejnej zdradzie małżeńskiej to sposób oddania zasadniczego rysu charakteru, czy raczej nasza własna małość albo pokusa „epatowania” odbiorców.

Oczywiście zarówno z prostych względów kompozycyjnych, jak i przede wszystkim z powodu poczucia dobrego smaku, przyzwoitości - nie wykorzystałem wszystkich mniej lub bardziej bolesnych opowieści, jakie zdarzyło mi się usłyszeć o Zbigniewie Herbercie. Paradoksalnie także dlatego, że zależało mi na obiektywizmie, wiem zaś, że to nie dobro, a zło przede wszystkim przyciąga uwagę odbiorców, że nawet drobnym skandalom łatwo jest przyćmić wydarzenia o wiele ważniejsze, cechy osobowości poety szlachetne, dobre, wzruszające. Wątpię jednak, by sam Herbert, niespodziewanie teraz wskrzeszony ze zmarłych, chciał w pełni zaakceptować taki swój wizerunek, jaki ja, przy najczystszych swoich intencjach, uważam za sprawiedliwy.

Ale jeśli duch bohatera rozliczy mnie kiedyś z mojej inteligencji, wrażliwości, wyobraźni, to czy ja z kolei mogłem temu bohaterowi uwierzyć, podążyć za jego własną opowieścią? Oczywiście nie sposób udzielić tu jednej generalnej odpowiedzi, jakkolwiek wydaje mi się, że wielu piszących dziś w Polsce biografów jest ode mnie bardziej bezwzględnych, z mniejszą wyrozumiałością rozlicza tych, o których pisze. Przyznam przy tym, że łatwiej mi było wierzyć w to, co mówił na swój temat Miłosz, natomiast już choćby wypowiedzi Herberta o walce w Armii Krajowej, napomknienia, których nie sposób było przyjąć za dobrą monetę, od razu podwyższały poziom czujności. Z pewną przesadą można to zresztą porównać do małżeńskiej zdrady, z powodu której niezwykle trudno jest odbudować raz zawiedzione zaufanie, pozbyć się podejrzliwości. A jeśli jeszcze, jak w przypadku autora Napisu, odkrywamy kolejne nieścisłości, konfabulacje - czy ostatecznie pieczołowicie opisywany bohater nie zaczyna budzić w nas i gniewu? Czy nie czujemy się zawiedzeni, nieledwie - właśnie - zdradzeni?

A jednak uważam, że nieufność, a nawet odsłanianie ewidentnych kłamstw, nie może prowadzić do zasadniczej niechęci, do pisania przeciwko bohaterowi; tak jak wspomnianych „żołnierskich" opowieści Herberta nie wolno podsumować łatwym osądem "mitomanii”, trzeba zrozumieć motywy, jakie kierowały tworzącym swój życiorys poetą. A czasem może wręcz nie trzeba zbyt drobiazgowo sprawdzać wszystkiego. Gdy bowiem wiem, że ciężko chory autor wiersza Pan Cogito szuka rady podczas swego pobytu w Izraelu 
nie był w stanie - jak o tym zapewniał - wspiąć się samemu na mury górskiej twierdzy Masada, to mimo wszystko lepiej będzie, jeśli na jakiś pozbawiony naiwności sposób spróbuję przynajmniej chcieć wierzyć, że mógł to zrobić. Zasadniczo rzecz biorąc, piękniejsze jest bowiem podążanie za zachwytem niż przyziemny zgorzkniały cynizm.

Bywa co prawda i tak, że o bohaterze dowiadujemy się zbyt wiele, że niektórych faktów wolelibyśmy nie poznać. I że np. sytuacja, w której do pewnych materiałów docieramy zbyt późno, czyli już po opublikowaniu książki, w zaskakujący sposób może sprawić nam ulgę. Wyjątkowo trudne było dla mnie pisanie o tym, że przynajmniej jeden z rozdziałów osobiście mi bliskiej książki, jaką jest Barbarzyńca w ogrodzie, można określić mianem, co tu kryć, plagiatu ${ }^{21}$. W gruncie rzeczy nie chciałem już szczegółowo roztrząsać (choć nie pominąłem tej sprawy), czy pomysł kształtujący wiersz Pan Cogito opowiada o kuszeniu Spinozy mógł poeta wprost zaczerpnąć z zapisków, skądinąd mało przez siebie cenionego, Kazimierza Brandysa ${ }^{22}$.Zaznaczyłem oczywiście fakt, że historycy sztuki nieraz krytycznie oceniają eseje Herberta, ale właściwie byłem zadowolony, że poetyka mojej książki nie pozwala mi na szczegółową analizę, że nie muszę drobiazgowo ukazywać, iż - jak szacuje ekspert - Martwa natura $z$ wędzidtem to "ponad 200 błędów i nieścisłości na jedynie 181 stronach", że błyskotliwe odczytanie napisu na tytułowym obrazie jest zwyczajnie błędne, co gorsza zaś fachowiec musi zauważyć: „tłumacząc na polski Johana Huizingę, irytowałem się, gdy odkrywałem, że «gdzieś» to już czytałem, a następnie znajdywałem u Herberta liczne zdania, a nawet akapity zapożyczone bez podania źródła..."23. I w gruncie rzeczy byłem zadowolony, gdy właśnie zbyt późno dowiedziałem się o istnieniu wiersza Wspomnienie $z$ Grecji, którego autorem był Tadeusz Hollender. Katalog biblioteki Zbigniewa Herberta podpowiada, że przynajmniej mógł on znać ten wiersz, kupił bowiem wybór utworów rozstrzelanego przez Niemców, starszego od siebie o pokolenie poety. Jeśli znał, to najwyraźniej zapamiętał powracającą tu,

Por. A. Franaszek Herbert. Biografia, t. 1, Kraków 2018, s. 755 i n.

22

Kwestię tę omawia szczegółowo, skądinąd ostatecznie cofając się przed ostatecznym rozstrzygnięciem, Ryszard Nycz w artykule „Niepewna jasność" tekstu i „wierność" interpretacji. Wokół wiersza Zbigniewa Herberta "Pan Cogito opowiada o kuszeniu Spinozy", w: Niepewna jasność tekstu. Szkice o twórczości Zbigniewa Herberta 1998-2008, red. J.M. Ruszar, Platan, Kraków 2009, s. 36-55.

P. Oczko Martwa natura w wędzidle stereotypu. Wizje sztuki holenderskiej Zbigniewa Herberta i problem z ich recepcjq, "Biuletyn historii sztuki” $2016 \mathrm{nr} 1$. 
a nawet będącą zasadniczym motywem konstrukcyjnym frazę „kato, kyrie, kato"24. Czy jednak zdawał sobie sprawę z tego, że powtarza cudze słowa, gdy frazę tę umieszczał we wspaniałej Modlitwie Pana Cogito - podróżnika?

„Jak to możliwe, iż człowiek tak niejednoznaczny, powikłany był autorem tak krystalicznych i zachwycających wierszy?" - pytają autorzy niektórych recenzji. Pytanie pada tyleż z głębi zrozumiałych i gwałtownych emocji, co jednak grzeszy naiwnością, ale przywołanie go prowadzi nas do najbardziej zasadniczej sprawy. Zapewne opisując każde życie, a już z pewnością życie artysty, biograf staje wobec tajemnicy. Musi przyznać, że nie potrafi wyjaśnić, jak powstaje obraz czy wiersz, jak następuje przeskok między chaosem zdarzeń, zapisanych myśli, uczuć, a spełnionym kształtem. Tym dziełem, które wyrasta oczywiście z gleby codzienności, często z gleby udręczeń, ale jednocześnie przekracza wszelkie znane nam uwarunkowania. Jako autor biografii Zbigniewa Herberta mogę wskazać konkretne miejsca, obrazy, osoby, do których odwołuje się Modlitwa..., czas i okoliczności jej powstawania, a nawet ewentualne, współtworzące ją, zapożyczenia, nigdy jednak nie przeniknę działania tworzącego ten utwór umysłu. Muszę pokornie pozostać przed tajemnica. Jak określiła to badaczka życia i twórczości Virginii Woolf, „, biograf powinien możliwie jak najsumienniej zrelacjonować bądź zrekonstruować wszelkie dostępne informacje i interpretacje. Jeżeli jednak doszłabym przy tym do przekonania, że nie pozostawiłam już żadnych zagadek ani tajemnic, znaczyłoby to jedynie, że sama padłam ofiarą najbardziej uwodliwego i najbardziej fałszywego mitu biografii"25.

\section{$* * *$}

Pod koniec życia Czesław Miłosz napomykał, że gdyby przyszło mu raz jeszcze rozpocząć poetycką drogę, to starałby się każdy wiersz poświęcić pojedynczej ludzkiej istocie, jej niepowtarzalnemu istnieniu. Virginia Woolf zaś,

24 Por. np.: „Na miniaturowego stateczku pokładzie, / na osiołku kroczącym asfaltową drogą, / w autobusie na szosie Ateny-Maraton, / (dzisiaj zowie się Saros - z barbarzyńska nieco) / gdy pytałem o drogę - kato, kyrie, kato... / - Idź naprzód, panie, naprzód... - a te gwiazdy świecą / wszędzie". Cytuję za wydaniem: T. Hollender Wspomnienie z Grecji, w tegoż Liryka i satyra, Wydawnictwo Literackie, Kraków 1963, s. 225-227; natomiast w bibliotece Zbigniewa Herberta odnajdziemy wybór wcześniejszy: Wiersze, satyry, fraszki, Książka i Wiedza, Warszawa 1949, także zawierający interesujący nas wiersz. $\mathrm{nr} 7 / 8$. 
myśląc co prawda o życiorysach przede wszystkim kobiecych, wyobrażała sobie miliony niewypowiedzianych historii, konkretnych ludzkich dziejów, z których „wszystko się rozpłynęło. W żadnej biografii ani historii tego nie odnotowano"26. Pisząc biografię, na swój sposób, oczywiście bardzo ułomny, znajdujemy się w podobnym punkcie. Na tyle, na ile potrafimy - wsłuchujemy się w głosy zmarłych.

Nie tylko tych, o których piszemy książki, ale również ludzi innych, których poznajemy poprzez naszego bohatera, a z którymi inaczej nigdy byśmy się nie zetknęli. Teraz jednak czytamy ich listy, zaczynamy darzyć sympatią, przebywamy wraz z nimi w dziwnej przestrzeni, zawieszonej między dwoma światami. Bo z jednej strony siedzimy samotnie w czytelni, powiedzmy londyńskiego POSK-u, gdzie za oknami przejeżdżają wagoniki metra, a ze szkolnego boiska dobiega wesoły gwar, ale z drugiej, otwierając kolejną teczkę, otrzymujemy ekstrakt cudzego życia, tak odległego od naszego czasu. Jesteśmy „tu”, ale również „tam” - we Lwowie lat 40., albo w Krakowie dwie dekady później, słyszymy głos, który dawno już umilkł, poznajemy nadzieje i plany młodości, kompromisy i rozczarowania wieku dojrzałego, nieuchronną samotność starości, a wszystko to nie w abstrakcyjnym uogólnieniu, a w najbardziej jednostkowej konkretności. Jakkolwiek zabrzmi to patetycznie, płacąc cenę smutku, odwiedzamy krainę śmierci - i z podróży tej wracamy odmienieni. Może nawet nieco mądrzejsi i bardziej wyrozumiali wobec żywych. Mniej przekonani o własnej nieomylności. Odrobinę mniej hałaśliwi. Pamiętający to zdanie Sándora Maraia: „wkraczam pomiędzy zmarłych, muszę więc ściszyć głos"27.

\footnotetext{
26 V. Woolf Własny pokój, w tejże Własny pokój. Trzy gwinee, przeł. E. Krasińska, Sic!, Warszawa 2003, s. 111. 


\section{Abstract}

\section{Andrzej Franaszek}

PEDAGOGICAL UNIVERSITY OF CRACOW

Before the Secret

Franaszek discusses the process of producing a biography. Drawing on accounts of other biographers as well as his own experience writing about the life and work of Czesław Miłosz and Zbigniew Herbert he asks what qualities mark a good biographer; he also discusses the specificity of the most important sources (such as a writer's archives or witness accounts). For Franaszek, a literary biography is situated in a space between academic writing and literature. Finally he explores the tenstion between the "objectivism" that is more or less available to the biographer and the readers' expectations, which the biographer often fails to meet.

\section{Keywords}

Zbigniew Herbert, life writing, biographer's work, writer's archive 